\title{
リビアの地下水開発について
}

—ワジアハマール拈よび ワジアルバブブロジェクト—— 志戸本佳孝* 植村 嘉之*

\section{Groundwater Resources Development in Libya}

-Wadi Ahmar and Wadi al Bab Project-

Yoshitaka SHIdomoto* and Yoshiyuki UemurA*

\begin{abstract}
The project of Wadi al Bab and Wadi Ahmar in Libya aims to deveplop the available water resources, both surface and groundwater. The study area is approximately $2,000 \mathrm{~km}^{2}$, located on the south-western flank of Jebel Akhdar Mountains, 30 to $80 \mathrm{~km}$ southeast of Benghazi.

The climate of the study area is semi-arid and its mean annual precipitation is 100 to $200 \mathrm{~mm}$ high. With First Escarpment as a border, to the west is spread the Benghazi coastal plain, and to the east, a table land. Tertiary rocks and Quaternary deposits are distributed. Each formation of Tertiary period displays transgressive and regressive facies and are comprised mainly of marine carbonates.

In this paper, some results of hydrogeological investigation, such as groundwater storage conditions, water quality, water balance and etc., will be discussed.

\section{I まえがき}

リビア国国土省は農産物の自給率向上を目的とし て, 表流水执よび地下水の水資源開発調查を八千代 エンジニヤリング侏に委託した。調查地域はベンガ ジ市の南東約30〜80 km に位固するワジ アハマー ル拈よび ワジ アルバブ 流域を中心とする2,000 $\mathrm{km}^{2}$ で, 現地調查は1979年 1 月より約 2 カ年にわた

*八千代エンジニヤリング株式会社

Yachiyo Engineering Co., Ltd.

り実施した。

ここでは，石乍岩地带での地下水調查の一例とし $\tau$, 地下水倵存状況, 水質, 水双支等须いての概 要を報告する。

\section{II 調查地域の概要}

1 地形 ・地質

調査地域は図-1に示すようにジャベルフクダ ール 山脈の南西端に位㯰する。標高200mの等高線 に治って NNW-SSE 系に走る此高差60～80mの急




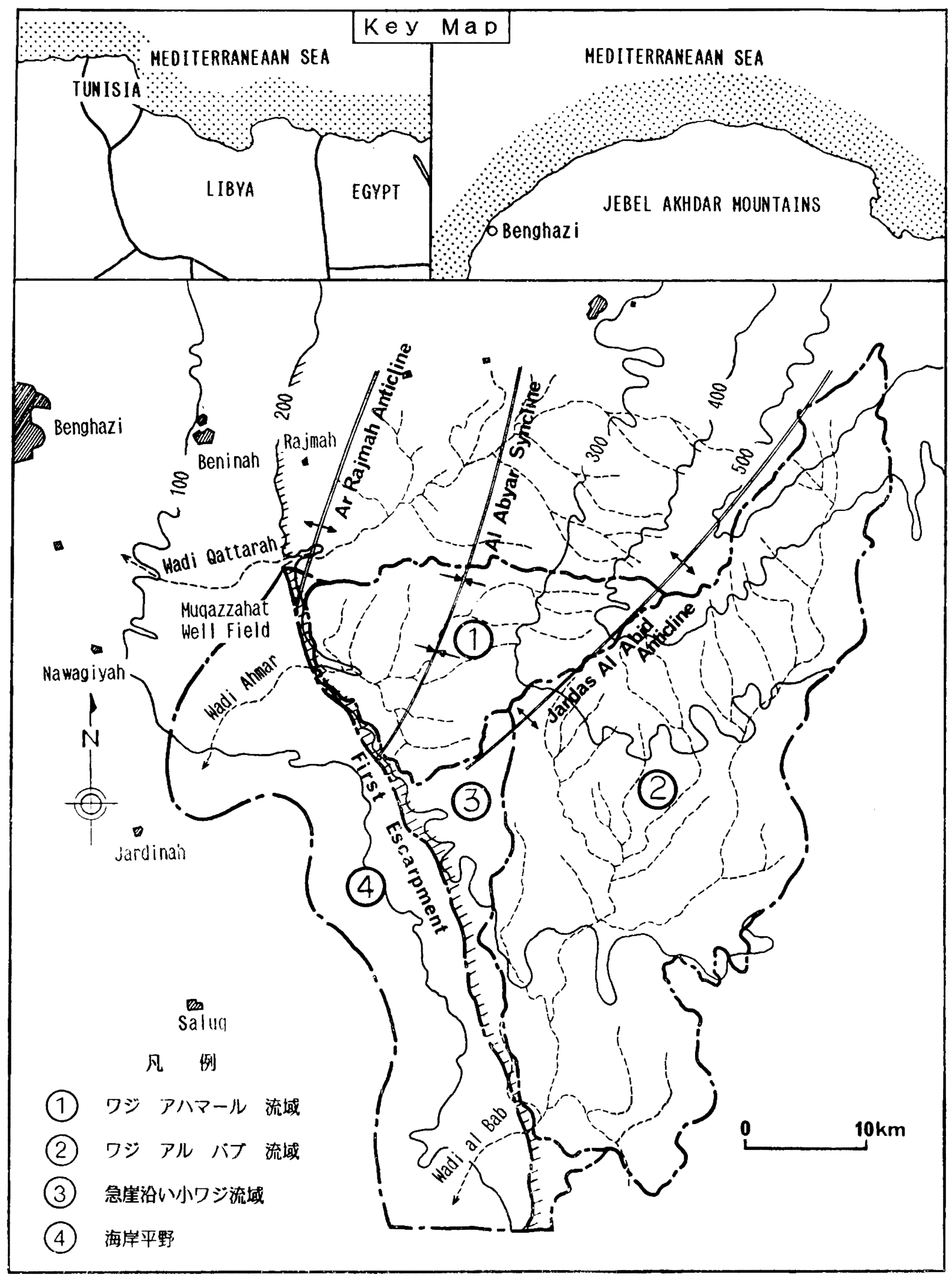

図-1調查地域位置図

Fig. 1 Location of study area. 
表-1 地管序

Table 1 Stratigraphical Classification

\begin{tabular}{|c|c|c|c|c|c|}
\hline \multicolumn{3}{|r|}{ 代 } & 地 & 岩 & $\dot{と}$ \\
\hline 第 & 四 & 紀 & & 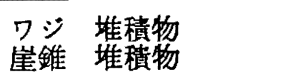 & 不整合 \\
\hline 第 & 中新世 & 中期 & Ar Rajmah 層 & $\begin{array}{l}\text { 石戌岩, 苦灰岩, } \\
\text { エパボ }\end{array}$ & 不整合 \\
\hline \multirow[t]{2}{*}{$\equiv$} & & 前期 & Al Faidiyah 層 & 石灭岩。苦可岩 & 不整合 \\
\hline & 漸 & 新 世 & Al Abraq 層 & 石灰岩, 苦灰岩, 粘土 & 不整合 \\
\hline 紀 & 始 & 新 世 & Derna 層 & 石灰岩, 苦欧岩 & \\
\hline
\end{tabular}

年平均気温は $20^{\circ} \mathrm{C}$ であり, 最高月平均気

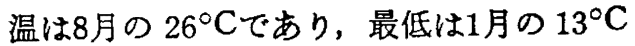
である。蒸発量についてはA級パンで3,000 $\mathrm{mm} /$ 年を越える。

調查地域は, 地形的に図-1に示すように ワジマハマール 流域 $\left(307 \mathrm{~km}^{2}\right)$, ワシ フ ルバプ 流域 $\left(1,085 \mathrm{~km}^{2}\right)$, 急崖沿いの小ワ 流域 $\left(148 \mathrm{~km}^{2}\right)$, 特よび海岸平野 $\left(463 \mathrm{~km}^{2}\right)$ の 4 つに大別される。ワジは雨期の比較的

崖（エスカープメント）が第一の地形的特徴となっ ている。この急崖より西側では, 平坦なベンガシ海 岸平野が拡がる。急崖より東側では, 南西傾斜の楥 やかな卓状地であり， ワジアルバブの最上流域 では，標高 500 mを越える。

調査地域の地質は第三系，第四系からなる。第三 系は主に，注泳平に堆積した海成の石灰岩からな ク，海進海退による層相の变化が認められる。また， 一部に粘土層やエパポライト層を介在している。第 四系は, ワジ堆積物および崖錐堆積物からなる。地 質層序は表-1に示すと扣りである。地下水は主に 急崖より西側の第三系中新統括よび漸新統の帯水層 から取水されている。

地質構造は図-1に示すようにアル ラジマ 背斜 軸, アル アビアール 向斜軸拈よび ジァルダス ア ルアビッド背斜軸により特徵づけられる。調査地 域内での断層は確認されていない。

カルスト現象としては、シンクホールがワジ ア ルバブの最上流域とジァルダスフルアビット背 斜軸の消隇部で見られる。また，ワジ狭穿部の露頭 では，層理面に沿って高さ数 $10 \mathrm{~cm}$ ，奥行き $2 \sim 3$ $\mathrm{m}$ の空洞が連続して見られる。

\section{2 水 文}

調查地域は半乾燥地带に属し，明蹽な雨期と乾期 をもつ。雨期は10月から翌年 5 月までで， 1 月， 2 月に最も多く降る。平均年降水量は100〜 $200 \mathrm{~mm}$ で あり，北側で多く，南側ほど少なくなる。
まとまった雨が降った時にのみ出水する。出水時の 流量および出水回数は年によりかなりの变動がある。

3 水利用形態

主食である小麦の栽培は雨期の天水を利用して行 なわれる。耕地はワジの氾濫原で, 表面に溝を切っ て引氷しやすくしている。栽培期間は 2 月から 5 月 までの 4 カ月である。

調㚗地域では, ベンガジ平野の ワジアルガター ラとワジハマールに摤まれたマグザ八地区で 良質の地下水が豊富に産出し（1 井当りの揚水量： $3 \sim 8 \mathrm{l} / \mathrm{sec}$ ), 揚水井 (深度 : 150 200m, 孔底口 径：8"〜10"）が集中している。ここでは，野菜， 果樹などの集約的な園芸農業が営まれている。この 地区では開発汸相当進んでいて，過剩揚水の兆候が 見られる。

その他の地区では，井戸の分布も点在して括り， 水質が良い場合には水量が得られなかったり，水量 が得られる場合には水質が悪かったりする。ここで の水利用形態は小規模な畑地耕作と羊を主とする家 畜の飼育である。

急崖下部のペディメントやワジの傾斜地では, 雨 水を導水し貯めて拈くためのシスターンが数多く見 られる。シスターンは $500 \mathrm{~m}^{3}$ 程度の規模で，领料用， 家畜用の地下の水溜である。

\section{III 水文地票調查}

1 調查の概要 
表 2 水文地梊調查一管表

Table 2 List of hydrogeological investigation.

\begin{tabular}{|c|c|c|}
\hline 調 查 項 目 & 的 & 内 \\
\hline 井戸台帳基本調査 & $\begin{array}{l}\text { 水利用, 所有者, 位圈, } \\
\text { 地下位, 地覔柱状 etc. } \\
\text { のデータ収集, 整理 }\end{array}$ & $\begin{array}{l}\text { 既設井 : 78井 } \\
\text { シスターン:338基 }\end{array}$ \\
\hline 地 質 踏 査 & $\begin{array}{l}\text { 地表地買把握 } \\
\text { 表層土犋把握 }\end{array}$ & 踏査面䅪 : 約 $2,000 \mathrm{~km}^{2}$ \\
\hline 電 気 探 查 & 地筫構造, 層序の把握 & 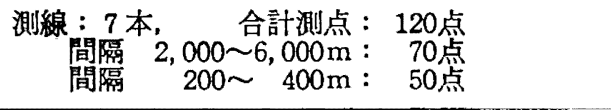 \\
\hline ボーリング調査 & $\begin{array}{l}\text { 㳟序の確認 } \\
\text { 㞗の確認 } \\
\text { 地算年代の判定 }\end{array}$ & $\begin{array}{l}\text { 調查孔 : } 13 \text { 井, 合計掘削深 : } 3004 \mathrm{~m} \\
\text { 孔茋口径: } 8^{n} 1 / 2 \sim 12^{n} 1 / 2 \\
\text { 検層 : } 13 \text { 孔, 化石分析 }: 2 \text { 孔 }\end{array}$ \\
\hline 揚 水 試 験 & 帯水層の性状把握 & $\begin{array}{l}\text { 試験井 : 13井 } \\
\text { 段階揚水試験, } 72 \text { 時間連続掦水武験 }\end{array}$ \\
\hline 地下水位測定 & $\begin{array}{l}\text { 地下水位変動特性把握 } \\
\text { 動水勾配の把握 }\end{array}$ & $\begin{array}{l}\text { 期間 : 䄪 } 2 \text { 年 } \\
\text { 観测井: 既設 } 24 \text { 井, 新設13井 }\end{array}$ \\
\hline 環境同位元素分析 & $\begin{array}{l}\text { 水萁年代の判定 } \\
\text { 地下皮函坦機構の把握 }\end{array}$ & 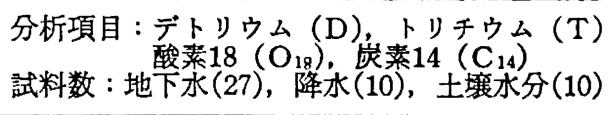 \\
\hline 水 質 分 析 & $\begin{array}{l}\text { 水質による地下水流動の把握 } \\
\text { 利のための評価 }\end{array}$ & $\begin{array}{l}\text { 分析項目 : } \mathrm{Na}^{+}, \mathrm{KO}_{4}^{+-}, \mathrm{HCO}_{3}^{+},{ }^{\mathrm{MCO}^{++}}, \mathrm{SiO}_{2}, \mathrm{Ca}^{++}, \mathrm{Cl}^{-} \\
\text {試料数 : } 102\end{array}$ \\
\hline
\end{tabular}

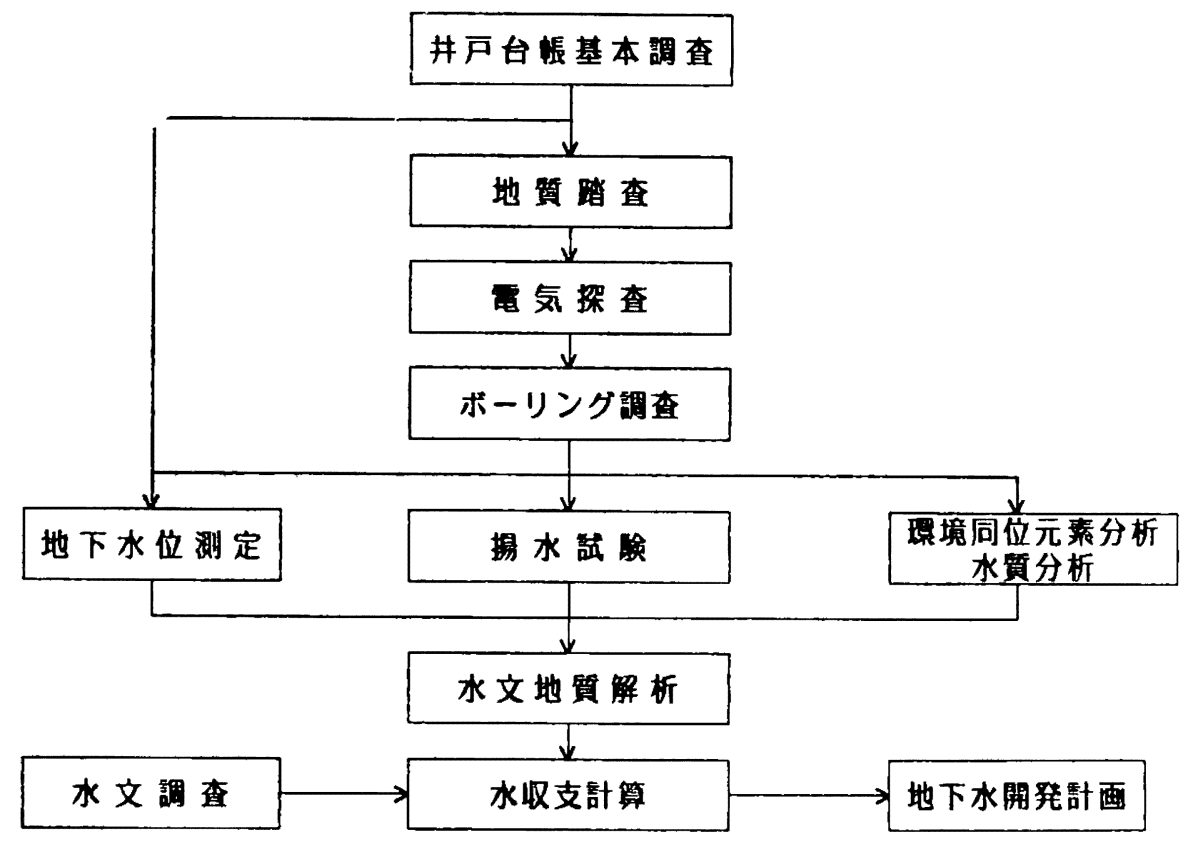

図-2 地下水開発調査フロー

Fig. 2 Flow chart of groundwater resources development investigation. 
地下水開発計画を立案するために，表一2に示す 水文地質調査を1979年 1 月から約 2 ケ年にわたり実 施した。

また，水文地質調查と並行して，雨量観測，流 量, 水位測定, 散水試験, 浸透能試験, $\mathrm{A}$ 級パンに 上る蒸発量測定，中性子水分計による土㖶水分測定 などを行なった。

各調査の相互関係を 図-2 の調查フローに示す。

\section{2 地下水賦存状況}

石灰岩地帯では，節理，層理，断層破碎帯などの 割れ目に沿って水が流れ，石灰岩を溶出して運び去 る。この結果, 複雑多岐なカルスト流路 (karst channel) が形成される。

調查地域で実施したボーリング調查でも，石灰岩 中に介在する粘土凬の直上で循環水の散逸, カッテ ングマテリアルの散逸，高産水ゾーンとの遭遇など のカルスト現象が認められた。しかし，ワジ河床下 の地下水流や断層破砕帯に沿って形成される大規模 なカルスト流路は見つからなかった。

石灰岩地帯での地下水位の分布は一般に不規則で あり，流れについても異方性が強く現われる。調査 地域内で地下水钼測井として選定した井戸の口元標 高は， 5 万分の 1 地図で読み取ったものが多い。こ
のため，水準測量と高感度高度計による計測を実施 して，井戸口元の標高を補正し，地下水位の測定精 度の向上飞努めた。

一方，地質構造より石灰岩の層理面がほぼ粘土層 に平行であるので, 粘土層を境界層と考元て地下水 面の連続性を検討し，比較的良好な結果が得られた。

これらの調查結果から，調查地域の地下水賦存状 況は概ね粘土層を境界層として図-3に示す 4 つに 大別できる。

（i）浅層宙水(Shallow perched aquifer):

この宙水は独立した宙水で地表面より比較的浅い層 準にあり，下流端で地下水面の不連続性が認められ る。

（ii）深層宙水 (Deep perched aquifer)：こ の宙水は下流側で帯水層に移行するすので，浅層宙 水より深い層準にある。

（iii）準帯水層 (Quasi main aquifer)：この 帯水層は(Iv)に述べる主帯水層と連続した水塊では あるが，上部層からの漏水，カルスト流路，粘土層 の介在などによって不規則な水頭分布を示す。

（iv）主帯水層（Main aquifer）：この带水層 は，過剩揚水による水頭低下ゾーンを除外した水頭 分布のうち, 最低水頭の放絡面と一致する水面形状

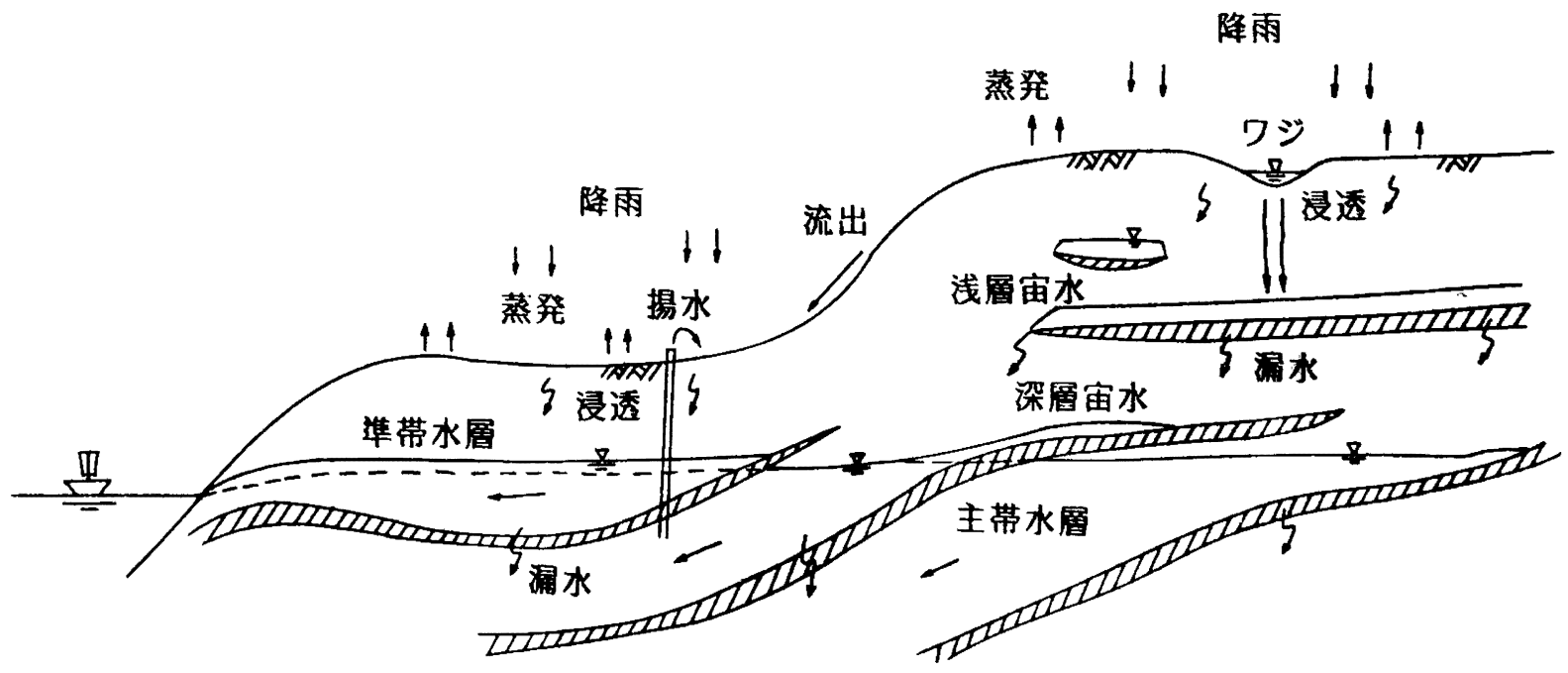

図-3 地下水流動概念図

Fig. 3 Delineation of groundwater system. 

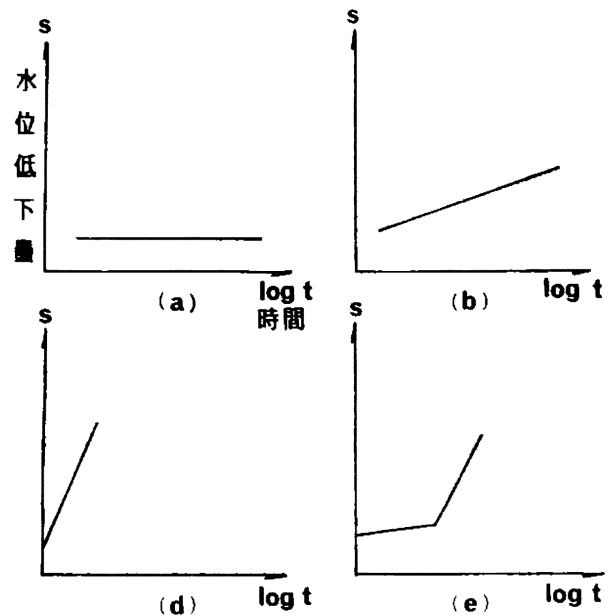

図-4 掦水試験における水位降下～時間曲線の形状

Fig. 4 Sharpes of drawdown change in time during pumping test

をもつ帯水層である。

この分類法は水収支計算を実施する上で，

主帯水䅉での大局的な地下水流動と主帯水層 以外の局所的な地下水流動とを分離すること によって，現象の把握が比較的簡単に行な⿱ る。

\section{3 揚水試験}

調査地域での揚水試験の水位降下〜時間曲 線の形状は図-4に示す6つのタイプに分け られる。また，各タイプの透水量係数は表-3 のように評価できる。

宙水での透水量係数は $10^{-5} \sim 10^{-6} \mathrm{~m}^{2} / \mathrm{s}$ 程度 であり，主带水層では山側で小さく，海側に 近つくにしたがって大きくなる（図-5参照）。

\section{4 水 質}

地下水の水質は図-6に示すようにT.D.S. 濃度 $1,250 \mathrm{ppm}$ 以下 では中間組成が多く, 2, 500ppm を越えるとほとんど全部がアルカ リ非炭酸塩類に属す。

陰イオンに対する重炭酸イオンの占める 比率が高ければ, 比較的 T.D.S. (Total Dissolved Solids 全溶解性残留物） 濃度が 低く，T.D.S.濃度が高くなるにしたがっ
て, 塩素イオン, 硫酸イオンの比率が增大す る。陽イオンでは, ナトリウムイオンの比率 が高くなる程，T.D.S.濃度が高い。

一方, トリチウムや炭素14による地下水 年代測定の結果からは，年代が新しくても

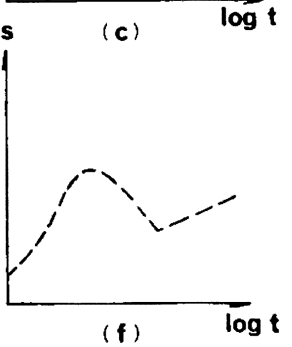

T.D.S.濃度が低いことや，T.D.S.濃度が 低くても年代の古いことが明らかになった。 このことは，石滴などのエバポライト層の影 響があるとしても，塩類の濃縮は主として表 層土壤に括ける蒸発の作用により起こること

\section{表-3 水位降下〜時間曲線の形状からみた透} 水量係数の值域

Table 3 Value range of transmissivity according to the sharp of drawdown change in time.

\begin{tabular}{|c|c|c|c|}
\hline 項 目 透水性 & 高 & 中 & 低 \\
\hline 透水舅保数 $\left(\mathrm{m}^{2} / \mathrm{s}\right)$ & $T>10^{-3}$ & $10^{-4}<\mathrm{T}<10^{-3}$ & $\mathrm{~T}<10^{-4}$ \\
\hline $\begin{array}{c}\text { 水位降下の 形 状 } \\
\text { (困-4参照) }\end{array}$ & a & $b, c, f$ & $\mathrm{~d}, \mathrm{e}$ \\
\hline
\end{tabular}

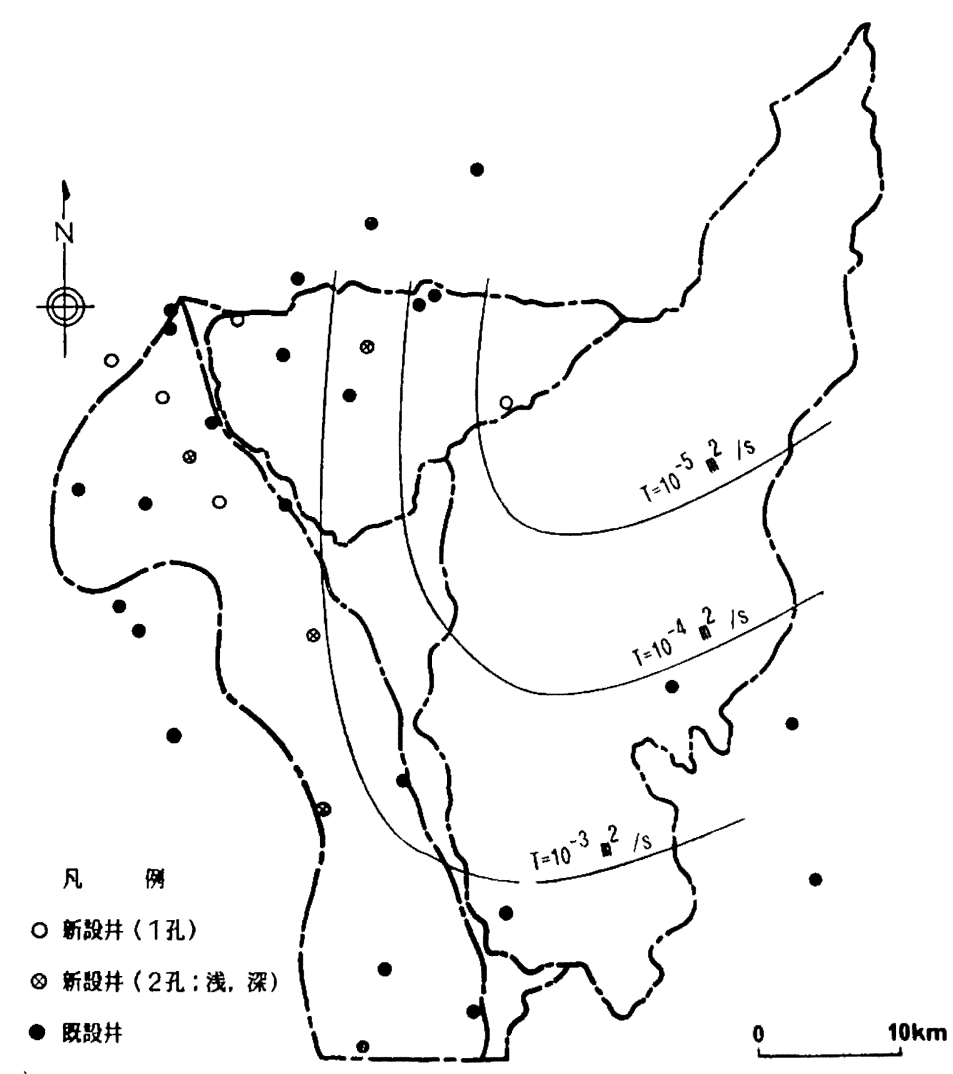

図-5 既設および新設地下水位観測并位置龱およひ主常水廉 6 透水量係数 Fig. 5 Location of existing new drilled wells for for piezometric observation and transmissivity of main aquifer. 


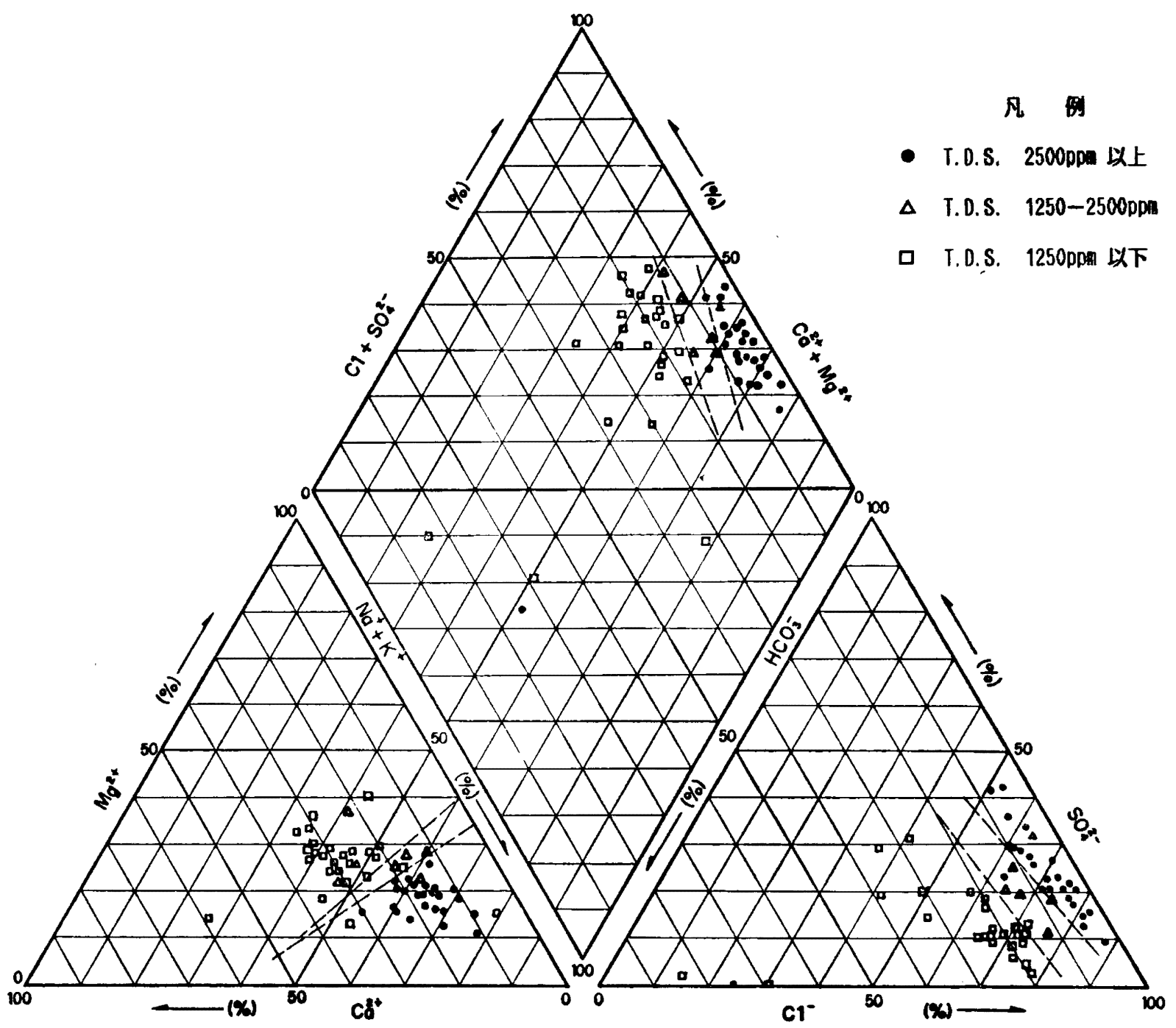

図-6 キーダイアグラム

Fig. 6 Key diagram

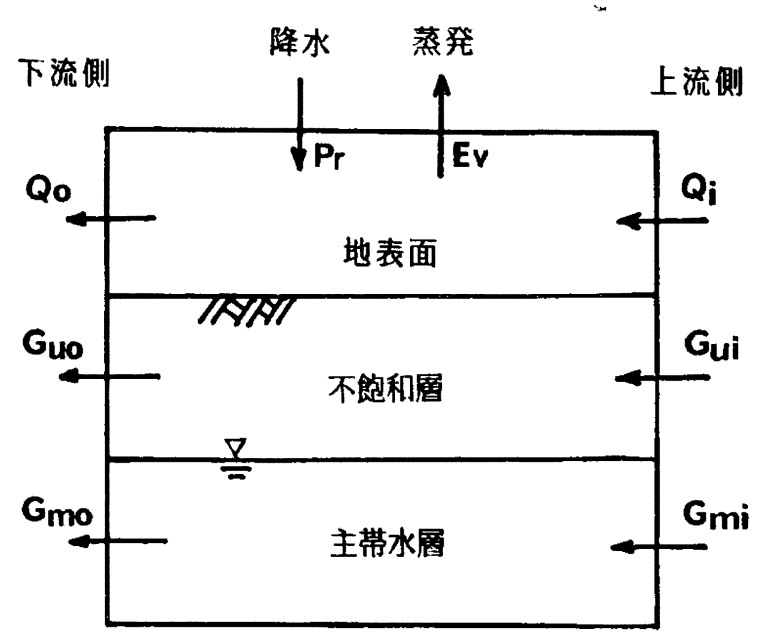

図一7 水収支モテル

Fig. 7 Model of hydrological water balance.
を示唆している。したがって, 降水量す少なく, 蒸 発ポテンシャルも高い調査地域南側のワジアル バブ 流域はT.D.S.濃度が総じて高い。

また，炭素14による地下水年代測定から，主帯水 層の地下水は 8,000 年以前のプルビフル(多雨期)に 涵養されたことが判明した。したがって, 主帯水層 の地下水流動速度は極めて遅いるのと考古られる。

5 水 収 支

水収支計算を行なら上での問題点は蒸発量と地下 水流量の評価である。蒸発量は土垬システムを考虑 した流出解析より算出した。地下水に関しては, 主 带水層とそれ以浅の層（広義に解积した不飽和層） 


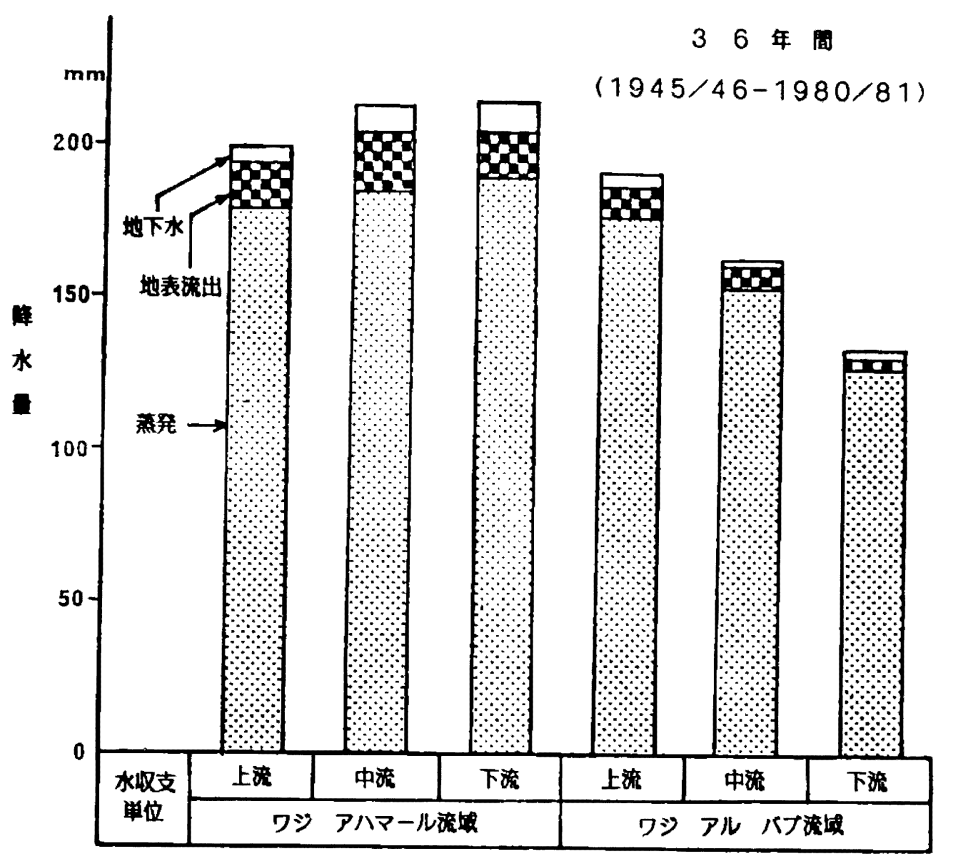

図-8 水収支要素が降水量に対して占める比率

Fig. 8 Water balance parameter portion to precipitation.

\section{N ま とめ}

調査地域は年降水量100～200mm の半乾燥 地带に属し, 年降水量のほとんどは蒸発で失 われ，地下への涵盖水量は極めて少ない。

炭素14による年代測定は，現在賦存してい る地下水の大部分が 8000 年以前の多雨期に涵 養されたことを示す。

調查地域は海成の石灭岩地帯であるが，大 規模なカルスト流路は見あたらなかった。ま た，水平方向の地下水流動は層理面に沿って 生じるものと仮定して解析を行なったが，水 質調查拉よび水収支計算との矛盾は生じてい ない。

地下水の賦存状況を浅㬝宙水, 深㬝宙水,

\section{に分けて検討した。}

水収支は図-7に示す水収支モデルを用いて次式 で表される。

$$
\begin{aligned}
\Delta S=P \mathrm{r} & -E \mathrm{v}+Q \mathrm{i}-Q \mathrm{o}+G \mathrm{ui}-G \mathrm{uo} \\
& +G \mathrm{mi}-G \mathrm{mo}
\end{aligned}
$$

ここで, $\Delta S$ : 地下水賦存量の增加量, $P \mathrm{r}$ : 降水 量, $E \mathrm{v}$ : 蒸発量, $Q \mathrm{i}$ : 表流水流入量, $Q \mathrm{o}$ : 表流水 流出量, Gui : 不飽和層での流入量, Guo : 不飽和層 での流出量, Gmi : 主帯水層での流入量, Gmo:主 带水普での流出量

（1）式を用いて，試行錯誤法により求められた水 収支の一例を図-8に示す。調查地域での降水量は ほとんど蒸発で失われてしまい，降水による地下へ の涵養量は極めて少ないことがわかる。

平均年で函養される地下水量を開発するとの仮定 に立つと，急崖の西側で 2.5 百万 $\mathrm{m}^{3} /$ 年 程度の揚水 は可能である。しかし，水質が恶いので表流水との 混合利用または淡水化を行なら必要がある。

この場合の水価は, 地下水 (か九水) の淡水化で は $1 \mathrm{~m}^{3}$ 当り $0.60 \mathrm{~L} / \mathrm{D}(1 \mathrm{~L} / \mathrm{D} \fallingdotseq 750$ 円）であり，表 流水との混合利用では $0.32 \mathrm{~L} / \mathrm{D}$ であった。 準帯水層和よび主帯水層の 4 つに大別することによ り，大局的な流動と局所的なものとが比較的容易に 識別できる。

最後に, 本プロジェクト遂行あたり，国際原子力学会 (IAEA), 国際水文地質学会(IHA)，CGG社(フランス), コスターアブラーム社 (キプロス), 棍谷調查工事(株), 株式会社日さく, リビアンファウンデーション, エスタブ リシュメント (LFE) 等闋係各位のご協力を得ました。こ こに厚くお礼を申しあげます。

\section{参考文献}

村下敏夫(1962)：『改著 地下水学要論』昭晃堂, 211p. 山 本荘毅ら，〔建設省水文研究グループ〕（1977）：『最新 地下水学』山海堂, 363p.

I.A.E.A. (1974) : Isotope Techniques in Groundwater Hydrology. Proc. Symp. Vienna Vol. 1, 2, 504p., 499p.

Todd D. K. (1959): Groundwater Hydrology. John Wiley \& Sons, Newyork, 336p.

Tolson J.S. \& Doyle F.L. (1975) : Karst Hydrogeo$\log y$. UAH Press. 578p.

（受付：1983年 8 月15日, 受理：1983年10月 4日） 